Eskişehir Osmangazi Üniversitesi

Sosyal Bilimler Dergisi

Nisan 2019, 20 (Özel Sayı), sayfa aralığı

DOI: 10.17494/ogusbd.

\title{
Rafadan Tayfa Çizgi Filminin Milli ve Evrensel Değerler Açısından Değerlendirilmesi
}

\author{
Şener ŞENTÜRK, Ayfer KESKIN*
}

\author{
Rafadan Tayfa Çizgi Filminin Milli ve Evrensel Değerler \\ Açısından Değerlendirilmesi \\ Özet
}

Bu Araştırmada "Rafadan Tayfa" adlı çizgi filmin milli ve evrensel değerler açısından değerlendirilmesi amaçlanmıştır. Doküman incelemesine dayanan araştırmada filmin 20 bölümü incelenmiştir. Verilerin analizinde Millî Eğitim Bakanlığı tarafından hazırlanmış olan kök değerlerden hareketle oluşturulan "içerik değerlendirme formu" kullanılmıştır. Filmde içeriğin en çok hangi değerlerle ilişkilendirildiği frekans ve yüzde ile sayısallaştırılarak sunulmuştur. Verilerin analizinde, evrensel değerlere ilişkin görsel sunumun milli değerlerin iki katı olduğu; milli değerlere ilişkin, gelenekler, mekanlar, kültürel miras, milli ve dini bayramlar; evrensel değerlere ilişkin, yardımseverlik, sevgi, saygı, dostluk değerlerinin ön plana çıktığı; milli ve evrensel kök değerlerin tamamına değinildiği görülmüştür. Bu doğrultuda filmin değerler üretimi ve aktarımı konusunda ciddi bir rol üstlendiği söylenebilir.

Anahtar Kelimeler: Çizgi Film, Milli Değerler, Evrensel Değerler, Rafadan Tayfa

\author{
Evaluation Of "Rafadan Tayfa" Cartoon In Terms Of \\ National and Universal Values \\ Abstract
}

The This research aims at evaluating a popular cartoon named "Rafadan Tayfa" in terms of national and universal values. Based on document analysis, 20 episodes were analyzed. During the analysis, a "content evaluation form" based on fundamental values of the Ministry of National Education (MEB) was used. The content is related with values and the relationship between the content and the value is pointed out with frequencies and percentage. As a result of the analysis, it can be stated that visual representation of universal values is twice as much the national values. Traditions, places, cultural heritage, national and religious holidays about national values come into prominence and helpfulness, love, respect and friendship are distinguished as universal values. Accordingly, it can be put forward that the cartoon has a significant role in producing and transmissing values..

Key Words: Cartoon, National Values, Universal Values, Rafadan Tayfa.

\section{Giriş}

Değerlerin çocuklara aktarımındaki ilk aktörler elbette doğal olarak aileleridir. Erken çocukluk döneminde ailede başlayan değer aktarım süreci, çevre, kitle iletişim araçları, okul gibi faktörlerle de çocuklara hayatın içinde verilmeye devam etmektedir. Aslında

\footnotetext{
*Şener ŞENTÜRK, Dr. Öğrt. Üyesi, Ondokuz Mayıs Üniversitesi, Eğitim Fakültesi, egitimhekimi@gmail.com, ORCID ID orcid.org / 0000-0002-0672-7820, Ayfer KESKiN, Öğretim Görevlisi, Ondokuz Mayıs Üniversitesi, Eğitim Fakültesi, akeskin@omu.edu.tr, ORCID ID orcid.org / 0000-0003-1655-2419
} 
Şener ŞENTÜRK | Ayfer KESKIN

değerler eğitiminin belli bir mekânı ve zamanı yoktur. Yaşamın her anında ve her yerde bu eğitim verilebilir. Ancak çocuklar üzerinde etkili olduğu dönemler vardır. Değer, Türk Dil Kurumu'na (TDK, 2011,s. 607) göre, "bir ulusun sahip olduğu, sosyal, kültürel, ekonomik ve bilimsel değerlerini kapsayan maddi ve manevi ögelerin bütünü" şeklinde tanımlanır. Değerler, pek çok kaynaktan beslenerek gelişmektedir ve özellikle küçük çocuklarda iyi davranışlara ilişkin deneyimlerin oldukça çeşitli olması önemlidir. Yaşam boyu devam eden bu süreçte temel değerlerin öğrenilmesi erken dönemde son derece önemlidir (Balat, 2004). Her kesimin kolaylıkla elde ettiği ve neredeyse her evde bulunan, en çok kullanılan kitle iletişim aracı olan televizyon ise hayat boyu süren değişimin abece'si olarak beyinleri kodlayabilmektedir.

Ses ve görüntü özelliklerini etkili kullanarak, eğlendiren, düşündüren, öğreten yapısıyla televizyon bir yandan toplumun özgün kültürünün aktarımını sağlarken diğer yandan baskın grupların yeni değerler üreterek hedef kitlenin hayatını, alışkanlıklarını, değerlerini, ideallerini değiştiren, toplumu öz kültürden uzak bir anlayışa sürükleyen kültürel endüstrinin bir aracı da olabilmektedir. Yaş farkı, eğitim düzeyi, okuma yazma becerisi gözetmeyen, genel bir izleyici kitlesine sahip olan, amaçlı programlardan, ticari kaygı ile hazırlanmış programlara kadar geniş bir yelpazeye sahip olan televizyonun çocuklar üzerinde etkisi ise yadsınamaz boyutta olduğu düşünülmektedir. Sanayileşme süreci ile annelerin de iş hayatına katıldığı günümüzde çocuklar için rol model konumuna geçen televizyon, Türkiye'de günlük bir ila on sekiz saat açık kalmaktadır. Bu süreç ise çocuğun bilişsel ve duyuşsal dünyasının şekillenmesinde önemli bir etkiye sahiptir (Cesur ve Paker, 2007). Yapımcısından senaristine, oyuncusundan sponsoruna kadar birçok farklı grubun kaygısını taşıyan televizyon, toplumdan beslenen ama toplumu yönlendiren bir güce sahiptir. Televizyonun etkin bir araç olarak kullanılmaya çalışılması izleyicilerin de sınıflandırılmasına zemin hazırlamış ve toplumdaki her yaş grubu için farklı programlar ve kanallar üretilmiştir. Televizyon yayınlarını en fazla izleyen gruplardan biri olan çocuklar için hazırlanan programlar, çocukları pasif ve bağımlı yapmakta, dolaysıyla sunulan içerikten de en fazla etkilenen kesim haline getirmektedir (Araboğa, 2018).

Özellikle çocuklar için tasarlanan kanallarda renk, ışık, ses ve hızlı değişen görüntülerle kasıtlı ya da kasıtsız, doğrudan ya da dolaylı birçok mesaj sunulmaktadır. Çizgi filmlerin bu renkli büyülü dünyasına kapılan çocuklar ise pasif bağımlı bir alıcı haline gelirken, duygusal gelişimden davranışlara, tüketim eğiliminden alışkanlıklara kadar birçok olumlu ve olumsuz duygu ve davranışı öğrenmektedirler. Çizgi filmlerde sunulan içeriğin toplumun bir yansıması, değerlerden oluşmuş olması, çocuğun gelişim özelliklerine uygun olması durumunda çizgi filmler, çocukların hayata ve topluma uyumları noktasında vazgeçilmez bir araç haline gelmiştir (Can, 1990). 
Çizgi film, karikatür, çizim, resim, kukla ve üç boyutlu nesneleri canlılarmış, hareket ediyormuş gibi göstermek için sinema tekniğinin grafik ve plastik sanatlara uygulanmasıdır. Çizgi film, Türk Dil Kurumu'nca yayınlanan Sinema ve Televizyon Terimleri Sözlüğünde "tek tek resimleri ya da devinimsiz nesneleri gösterim sırasında devinim duygusu verebilecek biçimde düzenlemek ve filme aktarma işi” (Hacıbektaşoğlu, 2014,s. 25); "Bir konuyla ilgili olarak karakterlerin hareketlerini belirtecek biçimde art arda çizilmiş resimlerden oluşan sinema filmi” olarak tanımlanmaktadır (TDK Türkçe Sözlük, 2011,s. 442). Çizgi film çocuklara yönelik bir medya içeriğidir. Masalsı bir dünyada gelişen olaylar ve masalsı kahramanlar ekrandan çocukların hayal dünyasına çizgi filmlerle akıverir. Tabii olarak bu medya içeriğinin de üretim ağırlığı ve kültürel damgası Batı imzasını taşır. Çizgi filmlerdeki dini törenler, çizgi film kahramanlarının inanış biçimleri, kutsal saydıkları şeyler çocuklar tarafından hemen benimsenebilir. Çizgi dünyanın tamamen sahte ve kurmaca dünyasının gerçekliğine inanan çocuk bilinci geliştikçe ilk dönemlerde çizgi filmlerden aldığı mesajların kalıntılarıyla başlangıçta şartlanmış olduğu konularda içinde olduğu geleneklere uyumda zorlanabilir. Ya da hiç zorlanmadan geleneğe yabancılaşabilir (Hacıbektaşoğlu, 2014, s. 27).

Devlet politikası gereği genel hedeflere ulaşmak için eğitimde değerler konusu temel eğitim ve lise müfredatlarında duyuşsal kazanımlar olarak önemli görülmüştür. 1739 sayılı Milli Eğitim Temel Kanununa ve Millî Eğitim Bakanlığı Stratejik Planına dayanan, 2010 yılında gerçekleştirilen 18. Milli Eğitim Şurasının da önemli konu başlıklarından olan değerler eğitiminin amacı genelde, "öğrencilere, bilgi, beceri, tutum kazandırmanın yanında onların dengeli, sağlıklı, gelişmiş bir kişiliğe ve karaktere sahip, temel ve insani değerleri kazanmış iyi insan, iyi vatandaş olarak yetişmelerini sağlamak" şeklinde açıklanmıştır. Toplumsal hayatı oluşturan, insanları birbirine bağlayan, gelişmeyi, mutluluğu ve huzuru sağlayan, risk ve tehditlerden koruyan ahlaki, insani, sosyal, manevi değerlerimizin tüm bireylere kazandırılmasında en önemli etken eğitimdir. Bu kazanımlarımızın öğrencilerimize aktarılması da değerler eğitimini oluşturmaktadır (MEB, 2010/53 Nolu Genelge). Ayrıca, geriye dönük olarak güncellenmiş olan öğretim programlarında yenilenmenin veya güncellemenin ana gerekçelerinden birinin de millî ve evrensel değerlerin kazandırılmasına verilen önemin yıllar içinde artmasıdır. O yıllardan bugüne kadar gerek örtük gerek doğrudan çerçeve programlar içinde tüm derslerde çoğunlukla ayrı değerler listesi yapılmış, "Eğitimde Değerler Eğitimi Programı (EDEP)" adı altında, okullarda belirli gün ve haftalar da göz önünde bulundurularak yaşama dönük etkinlikler (Ay Değer Temaları) şeklinde planlanmıştır.

Çizgi filmler yoluyla çocuklara milli ve evrensel değerlerin doğru aktarılması, mesajların çocuklar tarafından doğru algılanmasının sağlanması, yetiştirilmek istenen insan modeliyle dolayısıyla da toplumla alakalıdır. Bu doğrultuda MEB (2010) insan yetiştirme düzeninde değerler eğitiminin amacını, “öğrencileri, iyi insan, iyi vatandaş olmalarını sağla- 
Şener ŞENTÜRK | Ayfer KESKIN

yacak; millî, ahlaki, insani, manevi ve kültürel değerlerini benimseyen, koruyan ve geliştiren, bilgi beceri değer, tutum ve davranışlarla donatmak" şeklinde tarif etmiştir. Bu tanımın geçekleşmesinde önemli rolü olan çizgi filmlerin devlet tarafından desteklenen TRT Çocuk kanalında yer bulması ise devletin, kültürel aktarımda bireyin, toplumun ve çevrenin özgün yapısını korumaya dönük içerikleri desteklediği şeklinde yorumlanabilir.

\section{Türkiye'de Okullarda Değerler Eğitimi}

Türkiye'de UNESCO tarafından desteklenen "Yaşayan Değerler Eğitim Programı (YDEP)" adı ile 1995 yılında Birleşmiş Milletlerin 50. yıl dönümü kutlamalarına istinaden oluşturulan uluslararası bir projeye dayanmaktadır. Uluslararası boyutta eğitimcilerin bir araya gelerek "Yaşayan Değerler Eğitimi" adı verilen bu eğitim projesi demokrasi, adalet, özgürlük benzeri değerleri öğrenciye kazandırmada telkin yöntemi yerine, "Etkinlik temelinde" davranışları sıklıkla kullanmıştır. Ayrıca değerler eğitimine yönelik farklı yaş grubundaki öğrenci ve öğretmenler için malzemeler geliştirilmiştir (Cihan, 2014,s. 433).

Ülkemizde müfredatların giriş bölümüne "Değer(ler) Eğitimi” başlığı altında bir bölüm eklenerek değerlerin müfredatlarda yer alma nedenleri, nasıl yer aldığı, öğrenme öğretme sürecinde öğrencilere nasıl aktarılabileceği, değerler verilirken hangi öğretim yöntem ve tekniklerinin kullanılmasının gerektiğine ilişkin açıklamalara yer verilmiştir. Dersin bağlam ve kazanımlarından, konu anlatımından ve akışından kopuk olarak verilen değerler anlamIı ve kalıc olmamaktadır. Bu sebeple değerlerin ilgili dersin doğası ve müfredat kazanımları ile tutarlı olmasına ve bütünlük oluşturmasına dikkat edilmiş, aleni ve/veya örtük (zımnî, hidden) olarak müfredat kazanımlarına ve kazanım açıklamalarına hedeflenen değerler yedirilmiştir. Müfredat ile öğrencilere aktarılması hedeflenen kök değerler de şunlardır: adalet, dostluk, dürüstlük, öz denetim, sabır, saygı, sevgi, sorumluluk, vatanseverlik, yardımseverlik (TTK, 2017,s. 7-8). Yine temel dayanağını 1739 sayılı Milli Eğitim Temel Kanunu, Milî Eğitim Bakanlığı stratejik planı ve 18. Milli Eğitim Şurasından alan "Değerler Eğitimi" projesinin okullarda uygulanmasından öncelikle, her il için saptanan il Proje Yürütme Kurulları, İlçe Proje Yürütme Kurulları ve Okul Proje Yürütme Kurulu sorumlu tutulmuştur. Değerlerin işlenme sırası ise esnetilmiş, değerlere ilişkin önceliği değiştirme yetkisi il Yürütme Kurullarına verilmiştir. Kurulların kullandığı belirli bir zaman kesiti ile sınırları çizilmemiş olan ve eğitim-öğretim yılının geneline yayılmış olan değerler eğitim programı; "Sınıf İçi Etkinlikler, Okul İçi Etkinlikler ve Aileye Yönelik Etkinlikler" ile bütünlük içermektedir. Söz konusu etkinlikler, okul öncesi, ilköğretim ve ortaöğretim seviyelerinde, türlü branşlardan öğretmenlerin, rehber öğretmenlerin, okul idarecilerinin ve okul aile birliği üyelerinin oluşturduğu "Değerler Eğitimi Komisyonu” yoluyla gerçekleştirilen çalışmalarla, Millî Eğitim Bakanlığı tarafından önerilen faaliyet planı konuları ve kaynakları kullanılarak belirlenmektedir. 


\section{Çizgi Filmlerin Çocuklar Üzerindeki Etkisi}

Çizgi filmler bireyleri sunulan konuların içeriği dışında bu konuların sunuluş biçimi yoluyla da etkilemektedir. Bu nedenle, çizgi filmin yapısını oluşturan öğeler arasında anlatı önemli bir yere sahiptir. Çizgi filmlerin yapısı genellikle iki dramatik temele dayanmaktadır. Bunlardan birincisi bozulan bir şeyi, bir yanlışı onarmayı, araştırma ve geziyi; ikincisi ise, simgesel ve soyut amaçlar ve toplumsal bir durumla ilgili sonuç amaçları (yaşam, toplumsal düzen, korunmak) içerir. Kısa sarımlı yayınlanan birinci tür çizgi filmlerin amacı genellikle eğlence olurken ikinci sınıflandırmaya giren çizgi filmlerde ise ortaklaşa yapılan eylemlerin yer aldığı, gereksinimlerin bireye değil gruba ait oluğu bir yaklaşım söz konusudur (Yaşar, 2015, s.71). Bununla birlikte çizgi filmlerin eğlencenin ötesinde bir propaganda aracı olarak kullanıldığı da bilinen bir gerçektir. Örneğin, II. Dünya Savaşı sırasında Donald Duck'ın (Vak Vak Amca) çizgi filmde Hitler'e karşı oluşturduğu içerik, Kapitalist bir anlayışı ifade eden Richie Rich, kominizm propagandası yapan Şirinler, Nazi Propagandası yapan He-Man, Rus propagandası yapan Maşa bunlardan sadece bir kaçıdır.

Çizgi film karakterlerinin bir ürünün tanıtımında yer alması çocuğun ürünle beğendiği karakteri özdeşleştirerek o ürünün iyi olduğuna inanmasına ve satın alması gerektiğini düşünmesine neden olmaktadır. Oysa çocuklara yönelik reklamlarda bütün karakterler gerçek ve anonim kişilerden oluşmalıdır (Topçuoğlu, 2003, s. 77). Televizyonun çocukların zihinsel, ahlaki, ruhsal, kültürel ve sosyal davranışları ve gelişimleri üzerinde etkiler bırakabileceği düşüncesine birçok psikolog da katılmaktadır. Ailelerin çocuklarını yetişkin gibi davrandıklarını görmeleri onları mutlu etse de erken yaşta öğrenilen bazı olumsuz davranışlar psikolojilerini kötü yönde etkilemektedir (Hacıbektaşoğlu, 2014,s. 51).

Literatürde çizgi filmler aracılığıyla sunulan değerlerin ve sosyal davranış modellerinin çocukların davranışları üzerinde genel olarak etkili olduğu ortaya konmuştur. Gürhan (2017) tarafından Konya ilindeki 100 sınıf öğretmeninin ve 35 okul yöneticisinin görüşlerinin alındığı bir araştırmada, sınıf öğretmenleri Selçuklu Değerler Eğitimi’nin (SEDEP) öğrencilerde değerler konusunda farkındalık oluşturduğunu ve hoşgörü, cömertlik, saygı, sevgi, yardımlaşma, sabır, sorumluluk, temizlik gibi değerleri etkinlikler vasıtasıyla öğrendiklerini ifade etmişlerdir. Arıboğa (2018) tarafından yapılan bir araştırmada da çizgi filmlerin kültürel endüstrinin bir parçası olarak farklı değerler oluşturabileceği sonucuna ulaşılmıştır. Televizyonda yayınlanan çizgi filmlerin ilkokul ve ortaokul çağındaki çocukların tüketim alışkanlıklarına etkisinin araştırıldığı çalışmada Bitlis ilinde ilkokul ve ortaokul çağındaki 380 çocuğa anket uygulanmıştır. Araştırma sonucunda çizgi filmlerde çocukları etkileyen içeriklerin bulunmadığı ve çocukların satın alma davranışında rol oynayan ürünlere olan ilgilerinin de olumsuz olduğu tespit edilmiştir. Ünlü (2017) tarafından TRT Çocuk kanalındaki; Rafadan Tayfa, Canım Kardeşim, Maysa ve Bulut, Keloğlan Masalları, İstanbul Muhafızları çizgi filmler toplumsal cinsiyet rolleri bakımından incelenmiştir. Çizgi filmlerde toplumsal cinsiyet bakımından olumlu birtakım iletilere yer verilmesine rağmen hemen 
her karakterde olumsuz davranış özelliği kazandıracak iletilerin de mevcut olduğu, filmlerde toplumsal kalıp yargıların üretildiği, buradan hareketle TRT Çocuk kanalı çizgi filmlerinin toplumsal cinsiyet adına eşitlikçi bir anlayışa sahip olmadığı sonucuna ulaşılmıştır. Yorulmaz (2013) TRT Çocuk Kanalı'nda yayımlanan ve yerli bir yapım olan "Pepee" çizgi filmini "din ve değerler eğitimi" açısından incelemiştir. Pepee çizgi filminde; İslam dinine ilişkin herhangi bir dini sembol ve davranışa rastlanılmadığını, "sorumluluk, adalet, özgüven ve paylaşma vb." değerlere yönelik iletilere yer verildiğini saptanmıştır. Türkmen (2012) çizgi filmlerin kültür aktarımındaki rolü ve Pepee çizgi filmini izlemiş ve çizgi filmlerin birer kültür aktarım aracı olması kabulünden yola çıkarak, nasıl kullanıldıklarını tespit etmeyi amaçlamıştır. Bu araştırmalar doğrultusunda televizyonun ve çizgi filmlerin farklı amaçlar doğrultusunda farklı içerikler sunabileceği gerçeğine ulaşılabilir. Buradan hareketle, sunulan içerik hakkında araştırmalar yapılması hem kaynak sağlayıcılara birer dönüt niteliği taşıması bakımından, hem de genel izleyici kitlesinin çizgi filmlere ve üretilen değerlere ilişkin farkındalıklarının artırılması bakımından önem arz etmektedir.

Bu doğrultuda araştırmada, TRT Çocuk kanalında gösterilen Rafadan (Ramazan) Tayfa çizgi filminde milli ve evrensel değerlerden hangilerine yer verildiği ve değerlerin yer alma sıklıklarını tespit etmek amaçlanmıştır.

\section{Rafadan Tayfa Çizgi Filmi}

Rafadan Tayfa çizgi filmi 2014 yılında TRT Çocuk kanalında yayına başlamıştır. Prodüksiyonu Ankara'da yapılan macera türündeki bu animasyonun yapımcılığını ve yönetmenliğini İsmail Fidan üstlenmektedir. Hikâye, "Rafadan Tayfa" adındaki arkadaş grubunun yaşadığı maceralardan oluşur. Arkadaş grubunun ismi ise bir bölümünde Hayri'nin gruplarına bir isim bulurlarken Kafadan Tayfa yerine açlıktan Rafadan Tayfa demesinden ve onun çarpıcı bir isim olduğu için kabul edilmesiyle ortaya çıkar. Hikâyenin kahramanları şunlardır: Akın, Kâmil, Hayri, Mert, Sevim, Hale, Rüstem Abi, Basri Amca, Yumak, Fatma Nine, Saadettin Usta, Ankaralı Ozan . 
Araştırmaya dahil edilen bölümler Tablo 1'de verilmiştir.

Tablo 1. Araştırmada İncelenen Bölümler

\begin{tabular}{ll}
\hline \hline Rafadan Tayfa & \\
\hline Bugün Bayram & Pide Kuyruğu \\
Bayram Mendilleri & Orucu Ne Bozar \\
iftar Yemeği & Orucunu Tutmak \\
iftar Çadırı & Top Atılı ı \\
Pişi Dökme & Ramazan Arifesi \\
Ekmek Teknesi & Kazan Dairesi \\
Kadın İşi & Uçurtma Şenliği \\
Ufo Nöbeti & Define \\
Evlere Servis & İp Yumağı \\
Bir- İki- Üç- Tıp & Telsiz \\
\hline
\end{tabular}

\section{Yöntem}

\section{Araştırma Modeli}

Araştırmada nitel araştırma yöntemlerinden doküman analizi (içerik analizi) kullanılmıştır. Doküman analizi, araştırılması hedeflenen olgu veya olgular hakkında bilgi içeren materyallerin analizini kapsar (Yıldırım ve Şimşek, 2013).

\section{Çalışma Grubu}

Araştırmada, çalışmanın amacına hitap edecek bilgileri sağlayan durumlar tercih edildiğinden amaçlı örnekleme yöntemlerinden ölçüt örnekleme yöntemi kullanılmıştır (Johnson ve Chiristensen, 2014; Patton, 2014). Ölçüt olarak MEB'in milli ve evrensel değerleri (kök değerler) kıstas alınmıştır. Araştırmada çizgi filmin 2014 yılından beri yayında olduğu görülmüştür. Araştırma kapsamına alınan 20 bölümden 10'u tesadüfi olarak seçilirken, diğer 10 bölüm özellikle Ramazan ayında yayınlanan bölümler arasından tesadüfi olarak seçilmiştir. Ramazan ayının seçilmesindeki neden ise birey, toplum ve çevre şeklinde ele alınan değerler konusunun Ramazan ayına denk gelen bölümlerde daha fazla vurgu yapılıp yapılmadığını da ortaya koymaktır. Bu doğrultuda toplam 20 bölümden oluşan örneklem izlenerek metin haline getirilmiş, analizler yapılırken çizgi filmin hem görsel hem de metin halinden yararlanılmıştır. 
Şener ŞENTÜRK | Ayfer KESKIN

\section{Veri Toplama Aracı}

Doküman incelemesinde sadece yazılı belgelerin ötesinde film, video, fotoğraf gibi materyaller de doküman olarak kabul edilmektedir. Özellikle filmlerin birden fazla araştırmacı tarafından, birden fazla ve değişik aralıklarla izleme olanağı olması doküman incelemenin avantajlarıdır (Yıldırım ve Şimşek, 2013). Araştırmada Rafadan Tayfa çizgi filminin incelenmesi amaçlanmış ve bu doğrultuda okulların halen kullandıkları Millî Eğitim BakanIığı Talim ve Terbiye Kurulu Başkanlığı (2017) Müfredatta Yenileme ve Değişiklik Çalışmaları Üzerine Basın Açıklamasına ait hazırlanmış 10 kök değer (Ek-1) ve araştırma için kültüre özgü değerlerin yer aldığı, MEB'in 2010/53 Nolu Genelgesinde ifade edilen milli değerler eklenmiş olup, "İçerik Değerlendirme Formu” bu şekilde oluşturulmuştur.

Nitel araştırmalarda geçerlik bilimsel bulguların doğruluğunu, güvenilirlik ise tekrarlanabilirliğini konu edinir (Yıldırım ve Şimşek, 2013, s. 255). Araştırmanın geçerlik ve güvenirliğini artırmak üzere bazı tedbirler alınmıştır. Araştırmanın iç geçerliği (inandırıcılığı) için, literatürden faydalanılmış, Millî Eğitim Bakanlığının değerler eğitiminde ulaşılması hedeflenen milli ve evrensel değerler listesi temel alınmıştır. Oluşturulan formun ölçmeyi hedeflediği şeyi ölçüp ölçmediğini test etmek için uzman görüşü alınmıştır (Tavşancıl ve Aslan, 2001).

Araştırmanın dış geçerliliği (aktarılabilirliği) için araştırma basamakları detaylı bir şekilde açıklanmıştır.

Araştırmanın güvenirliğini (tutarlığını) artırmak için filmler üç farklı kişi tarafından izlenerek kodlanmıştır. Kodlama için MEB (2017) kök değerler ve bu değerlere ilişkin alt oluşturulan kontrol listesi ve kök değerlere ilişkin tutum ve davranışlar temel alınmıştır. Verilerin sağlıklı bir şekilde düzenlenmesi ve birleştirilmesi için çizelge oluşturulmuştur. Örnekleme dahil edilen bölümlerde kök değerlere ilişkin tutum ve davranış sıklıkları çizelgeye işaretlenmiştir. Üç farklı izleyici tarafından yapılan işaretlemelerin birbiri ile olan tutarlılıkları göz önüne alınarak sonuçlar biçimlendirilmiştir. Kodlamalar arası tutarlılığın Miles ve Huberman (1994)'a göre en az \%70 olması kuralı dikkate alınmıştır. Farklı zamanlarda farklı kişiler tarafından yapılan kodlama tutarlılık oranı \%88 bulunmuştur.

\section{Verilerin Analizi}

Araştırmada verilerin analizinde, verilerin tanımlanması, kodlanması ve kategorilere ayrılarak yorumlanmasını sağlayan içerik analizi kullanılmıştır. İçerik analizlerinden tümdengelimci bir yolun izlendiği araştırmada verilere ilişkin öncelikli olarak kategoriler belirlenmiş, bu kategorilerden hareketle filmdeki kelime, cümle veya görsellere ilişkin durum- 
lar sayılarak frekanslar oluşturulmuş ve elde edilen veri setleri yorumlanmıştır (Silverman, 2001).

\section{Bulgular}

Araştırmanın amacına yönelik olarak araştırma için "Milli ve Evrensel "Değerlere ilişkin bulgular Tablo'2 de verilmiştir.

Tablo 2. Milli ve Evrensel Değerlere Illişkin Frekans ve Yüzdeler

\begin{tabular}{lccccccc}
\hline \hline \multirow{2}{*}{ Değerler } & \multicolumn{2}{c}{ Rafadan Tayfa } & \multicolumn{2}{c}{ Ramazan Tayfa } & \multicolumn{2}{c}{ Toplam } \\
& & $f$ & $\%$ & $f$ & $\%$ & $f$ & $\%$ \\
\hline Milli Değerler & 18 & 22,22 & 56 & 34,36 & 74 & 30,33 \\
Evrensel Değerler & 63 & 77,78 & 107 & 65,64 & 170 & 69,67 \\
Toplam & 81 & 100,00 & 163 & 100,00 & 244 & 100,00 \\
\hline
\end{tabular}

2014 yılında yayınlanmaya başlanan Rafadan Tayfa'da milli değerlere ilişkin 18 defa vurgu yapılırken evrensel değerlere ilişkin 63 defa vurgu yapılmıştır. Değerlere ilişkin bu sıklığın Ramazan Tayfa'da milli değerlerde üç kat, evrensel değerlerde ise iki kat arttığı görülmüştür. Bu durumun ise çizgi filmin senaryosunun Ramazan ayına uygun, özel bir içerikle oluşturulmuş olmasından kaynaklandığı düşünülmektedir. Genel itibari ile çizgi filmde evrensel değerlere daha çok yer verildiği $(\% 69,67)$ görülmüştür.

Rafadan Tayfa çizgi filminde yer alan Evrensel Değerlere ilişkin bulgulara ait frekans ve yüzdeler Tablo 3'te verilmiştir.

Tablo 3. Evrensel değerlere ilişkin bulgular

\begin{tabular}{lllllll}
\hline \hline \multirow{2}{*}{ Evrensel Değerler } & \multicolumn{2}{l}{ Rafadan Tayfa } & \multicolumn{2}{l}{ Ramazan Tayfa } & \multicolumn{2}{c}{ Toplam } \\
& $f$ & $\%$ & $f$ & $\%$ & $f$ & $\%$ \\
\hline Adalet & 2 & 3,17 & 6 & 5,61 & 8 & 4,73 \\
Dostluk & 4 & 6,35 & 9 & 8,41 & 13 & 7,69 \\
Dürüstlük & 3 & 4,76 & 9 & 8,41 & 12 & 7,10 \\
Özdenetim & 1 & 1,59 & 9 & 8,41 & 10 & 5,92 \\
Sabır & 4 & 6,35 & 5 & 4,67 & 9 & 5,33 \\
Saygı & 6 & 9,52 & 15 & 14,02 & 21 & 12,43 \\
Sevgi & 11 & 17,46 & 13 & 12,15 & 23 & 13,61 \\
Sorumluluk & 5 & 7,94 & 3 & 2,80 & 8 & 4,73 \\
Vatanseverlik & 6 & 9,52 & 6 & 5,61 & 12 & 7,10 \\
Yardımseverlik & 21 & 33,33 & 32 & 29,91 & 53 & 31,36 \\
Toplam & 63 & 100,00 & 107 & 100,00 & 170 & 100,00 \\
\hline
\end{tabular}


Araştırmaya konu olan değerlerden, Evrensel değerlerin çizgi filmde kök değerlerin tamamına değinildiği görülmüştür. Bu değerlerden en çok vurgulanan Yardımseverlik $(f=53)$ değeri olmuştur. Bu değere "Ekmek Teknesi" bölümünde sokakta bulunan köpeğin eve alınıp, aşı ve bakımlarının yapılması ya da "iftar Çadırı" bölümünde mahallelinin imece usulü yemekler yapıp çadıra götürmesi, "Pide Kuyruğu" bölümünde mahalledeki çocukların bakkala yardım etmesi ve pide kuyruğuna girmesi "Kadın İşi” bölümünde; Yaşlılar haftası olduğunu arkadaşlarıyla paylaşan Sevim ve Hale'nin Basri amcaya ev ve bahçede yardım etmesi örnek olarak gösterilebilir. En az işlenen Evrensel değerlerden biri; Sorumluluk ( $f=8$ ) diğeri ise Adalet ( $f=8$ ) değeri olmuştur. Bu değere; "Ekmek Teknesi” bölümünde Rüstem abinin köfte arabasının kaza ile tekerinin kırılmasından sorumlu olan mahalle çocuklarının, tekerleğin tamirinde görev almaları örnek olarak verilebilir.

"Yardımseverlik" ve "Sevgi" gibi evrensel değerlere çizgi filmde daha fazla yer verilmiştir. Bunun bir nedeni de yardımseverliğin Türk milletinin karakteristik kodlarından biri olmasıdır. Ayrıca Türkiye'ye ülkelerinde ki savaş nedeni ile zorunlu olarak göç eden Suriyeli insanların yaşadıkları sosyal olay ve sorunlar, dünyanın farklı coğrafyalarında yaşanan fakirlik, kıtlık gibi sorunlara karşı hassasiyetin aktarılmasında etken olmuş olabilir. 2-6 yaş arasında "benmerkezci" duygulara sahip ve yardımseverlik duyguları henüz gelişmemiş olan çocuklara bu dönemde çizgi filmler aracılığı ile bu değerlerin öğretilmesi büyük önem taşımaktadır. Bu noktada çizgi filmin, özellikle ilk çocukluk evresine geçişte, dış dünya ile (mahalle, komşu, esnaf, hayvanlar vb.) iletişimin nasıl kurulacağına dair eğitici, öğretici ve eğlendirici yönü çocuğun sosyal gelişimi açısından son derece önemli bir yere sahiptir. Adalet $(f=8)$, sorumluluk $(f=8)$ ve sabır $(f=9)$ değerlerine daha az yer verilme nedeni olarak, bu değerlerin bu gelişim dönemi çocukları için soyut bir kavram niteliğinde olması gösterilebilir.

Küreselleşmenin dünyayı tek tipleştirmeye götürdüğü düşünülürse en küçük bir kültürel farklılığı dahi dünyayla buluşturmak, milli değerleri korumakla mümkündür. Bu sebeple araştırmada milli değerlere de yer verilmiştir. Rafadan Tayfa çizgi filminde yer alan milli değerlere ilişkin bulgulara ait frekans ve yüzdeler Tablo 4'te verilmiştir.

Tablo 4. Milli Değerlere İlişkin Bulgular

\begin{tabular}{|c|c|c|c|c|c|c|}
\hline \multirow{2}{*}{ Milli Değerler } & \multicolumn{2}{|c|}{ Rafadan Tayfa } & \multicolumn{2}{|c|}{ Ramazan Tayfa } & \multicolumn{2}{|c|}{ Toplam } \\
\hline & $f$ & $\%$ & $f$ & $\%$ & $f$ & $\%$ \\
\hline Aile & 1 & 5,56 & 6 & 12,50 & 7 & 10,61 \\
\hline Gelenekler & 3 & 16,67 & 10 & 20,83 & 13 & 19,70 \\
\hline Kültürel miras & 4 & 22,22 & 7 & 14,58 & 11 & 16,67 \\
\hline Misafirperverlik & - & - & 5 & 10,42 & 5 & 7,58 \\
\hline
\end{tabular}


Eskişehir Osmangazi Üniversitesi Sosyal Bilimler Dergisi

\begin{tabular}{lllllll}
\hline Milli ve Dini bayramlar & - & - & 9 & 18,75 & 9 & 13,64 \\
Türkçe & - & - & 9 & 18,75 & 9 & 13,64 \\
Mekânlar & 10 & 55,55 & 2 & 4,17 & 12 & 18,18 \\
Toplam & 18 & 100 & 56 & 100,00 & 66 & 100,00 \\
\hline
\end{tabular}

Çizgi filmin örnekleme alınan kısmında milli değerlerden en az Misafirperverlik ( $f=5$ ) değerine yer verildiği görülmüştür. Bu değere ilişkin örneğin "Bugün Bayram" bölümünde Basri Amca'nın misafirler için şeker almaya gitmesi, bahçede oturan Sadettin Usta'ya mahalleli çocuklarının bayram şekeri adetini hatırlatması verilebilir. Bayramda oturmaya gidildiğinde sırayla tekrar tekrar "Nasılsın?" sorusunun ev sahibince sorulmasının gelenek göreneklerimizde olduğunun sözel olarak Hayri tarafından söylenmesi örnek olarak verilebilir. Çizgi filmde en çok yer verilen değerin gelenekler $(f=13)$ değeri olduğu görülmüştür. Bu değere ilişkin "Pişi Dökme" bölümünde Ramazanda mahalleliye Fatma Nine ve Basri Amca'nın pişi dağıtması, “iftar Çadırı” bölümünde Hayri'nin yemek tencerelerini çadıra götürürken arkadaşlarından saklaması örnek olarak verilebilir. Yine çizgi filmin Ramazan bölümlerinin başlangıcında manilerin okunup, davul çalınması, mahallede oynanan çocuk oyunlarına yer verilmesi, "Bugün Bayram" bölümünde çocukların bayramlaşma için Sadettin Usta, Rüstem Abi, Fatma Nine'ye gitmesi büyüklerin elini öpme adeti, Basri Amca'nın çocuklara bayramlık kıyafet alması, Fatma Nine'nin bayramda çocuklara şeker ve mendil hediye etmesi geleneklere ilişkin örnekler olarak verilebilir. İkinci olarak milli değerler içinde en sık Mekânlara ( $f=12$ ) yer verilmiştir. Bu değere Rafadan Tayfa'nın tanıtımında yer alan İstanbul manzaraları; Boğaz, köprü, Marmara denizi, cami vb... mekanlar görseller olarak örneklendirilebilir. Milli değerlerin sayısının Ramazan Tayfa bölümlerinde artmasının bir nedeni olarak da dizinin bu bölümlerinin Ramazan ayına uygun amaçlı, planlı bir içerikle oluşturulmuş olmasından kaynaklandığı da söylenebilir.

\section{Tartışma Ve Sonuç}

Bu araştırmada TRT Çocuk Kanalı'nda yayınlanmakta olan Rafadan Tayfa çizgi filmi milli ve evrensel değerler açısından incelenmiş, filmde tüm değerlere (10 kök değer) yer verildiği görülmüştür. Değerlerin "sözel ifade" ve davranışsal ifade açısından" çizgi filmde yer alma sıklıklarına ilişkin ifadelerin incelenmesi sonucunda: evrensel değerlere ( $f=170)$, milli değerlerden ( $f=74$ ) daha çok yer verildiği tespit edilmiştir. En fazla vurgulanan evrensel değerin "yardımseverlik $(f=53)$ ve milli değerlerde "gelenekler $(f=13)$ " değeri olduğu görülmüştür.

Milli ve evrensel değerlere ilişkin toplumsal ilk algıların oluşmaya başlayıp, değerlere ait temel bilgilerin kazanıldığı kritik bir dönem olan okul öncesi ve somut işlemler döneminde, çocuklar tarafından sıklıkla izlenen program türlerinden çizgi filmlerde değer ifadelerinin içerikte davranış modelleriyle çocuklara sunulması, değerin davranış olarak kazanılması açısından büyük önem taşımaktadır. Bununla birlikte söz konusu değerlerin 
Şener ŞENTÜRK | Ayfer KESKIN

davranışa dönüştürülüp dönüştürülmeyeceği bilinmemekle birlikte Rafadan Tayfa'nın değer aktarımına katkı sağlayacağı düşünülmektedir.

Araştırmaya benzer bir çalışma da Akıncı (2013), tarafından yapılmıştır. Okulöncesi kategorisinde yayınlanmakta olan çizgi filmlerde değerlerin "sözel ve davranışsal ifade" açısından sunulma biçimlerinin çizgi filmlerde yer alma sıklıklarını tespit edildiği araştırmada "nezaket, mutluluk, sevgi, arkadaşlık, özgüven, sabır, saygı, cesaret, temizlik, yardımlaşma, paylaşma, sorumluluk, empati, doğruluk (dürüstlük) ve iş birliği" olmak üzere 15 farklı değer kategorisi bulunmuştur.

Özdaş (2013) tarafından yapılan "ortaokullarda değerler eğitimi ve istenmeyen öğrenci davranışlarına ilişkin öğretmen görüşlerinin değerlendirilmesi" başlıklı araştırmada da değerler milli ve evrensel olarak ele alınmıştır. Araştırma 34 (30 resmi ve 4 özel okul) okulda görev yapan 545 resmi okul ve 45 özel okul öğretmeni ile yürütülmüş ve araştırma sonucunda ortaokul öğretim programlarında yer alan değerlerden "Bireyler arası ilişkiler" "Milli Değerler", "Evrensel Değerler" ve "Özerklik" boyutlarındaki değerlerin "Kısmen Yeterli" düzeyinde kazanılmış olduğu belirlenmiştir.

Dereli-İman (2014) tarafından, "okul öncesi dönem çocukları için geliştirilmiş olan değerler eğitimi programının çocukların sosyal beceri, psiko-sosyal gelişim ve sosyal problem çözme becerilerine etkisinin incelenmesi" amacıyla yapılan araştırma sonucunda, değerler eğitimi programına katılan çocukların sosyal beceri, psiko-sosyal gelişim ve sosyal problem çözme becerileri puan ortalamalarının eğitim programına katılmayan çocukların puan ortalamalarından anlamlı düzeyde yüksek olduğu bulunmuştur.

Atabey (2014) okul öncesi sosyal değerler kazanımı ölçeğinin geliştirilmesi ve sosyal değerler eğitimi programının anasınıfına devam eden çocukların sosyal değerler kazanımına etkisini incelediği araştırmasında sosyal değerler eğitimi programının ana sınıflarında uygulanmasının okulöncesi öğrencilerinde kalıcı olduğunu sonucuna ulaşmıştır.

Sapsağlam (2015) tarafından yapılan "anasınıfına devam eden çocuklara uygulanan sosyal değerler eğitimi programının sosyal beceri kazanımına etkisinin incelenmesi" adlı araştırma sonucunda sosyal değerler eğitimi programının, çocukların sosyal beceri kazanımında etkili olduğu ve bu etkinin kalıcı olduğu bulgusuna ulaşılmıştır.

Araştırma sonucunda Rafadan Tayfa çizgi filminde yer alan değerlerin, niteliksel (kategori) ve niceliksel (sayı) açıdan çocuk izleyiciye sunulduğu görülmüştür. Benzer çalışmalarda da araştırmayı destekleyen sonuçlara ulaşıldığı ve çizgi film senaryolarında toplum- 
sal yaşamı düzenlemekte etkili olan milli ve evrensel değerlerin değerler aktarımına katkı sağlayabileceği söylenebilir.

\section{5. Öneriler}

1-Yerli yapım çizgi filmlerin sayısının arttırılarak değerler eğitimi açısından çocukların kendi kültür ve tarihini daha iyi anlamaları sağlanabilir.

2- Millî Eğitim Bakanlığı, değerler eğitiminde çizgi film karakterlerinden yaralanabilir. Bu hem aileye değerlerin öğretiminde ortak bir dil desteği sağlarken hem de birlik bilincine inanmış kişi sayısı yönünden devletin devamlılığına hizmet edebilir.

3- Milli değerlere ilişkin çizgi filmlerle içerikler hazırlanabilir. Bu konuda çizgi film metin yazarlarına zorunlu (Pedagog, Tarihçi, Eğitimci vd....) destek verilebilir.

4- Yerli yapım çizgi filmlerin sayısı ve içeriği değerler eğitimi bakımından zenginleştirilebilir

5- Değer aktarımı konusunda incelenen çizgi filmlerin davranış değiş̧ikliğine sebep olup olmadığı araştırılabilir.

\section{Kaynaklar}

Akıncı, A. (2013). Okul öncesi döneme yönelik hazırlanan çizgi filmlerde değerlerin sunumu: TRT çocuk kanalı örneği. Yayımlanmamış yüksek lisans tezi, Ankara: Gazi Üniversitesi.

Araboğa, E. (2018). Çizgi filmler ve tüketim kültürü: Çizgi filmlerde tüketim davranışlarının ve tüketim nesnelerinin ilkokul ve ortaokul çağındaki çocuklara etkisi. Yayımlanmamış yüksek lisans tezi, İstanbul: İstanbul Arel Üniversitesi.

Atabey, D. (2014). Okul öncesi sosyal değerler kazanımı ölçeğinin geliştirilmesi ve sosyal değerler eğitimi programının anasınıfına devam eden çocukların sosyal değerler kazanımına etkisinin incelenmesi. Yayınlanmamış doktora tezi, Ankara: Gazi Üniversitesi Eğitim Bilimleri Enstitüsü.

Balat, U.G. (2004). Çocuklar ve değerler eğitimi. Çoluk Çocuk Dergisi, 8. (45), 18-20.

Can, A. (1990). Televizyonda okul öncesi çocuklara yönelik Susam Sokağı programı. Yayımlanmamış yüksek lisans tezi, Eskişehir: Anadolu Üniversitesi 
Şener ŞENTÜRK | Ayfer KESKIN

Cesur S, Paker O. (2007). Televizyon ve çocuk: Çocukların TV programlarına ilişkin tercihleri. Elektronik Sosyal Bilimler Dergisi. 6. (19), 106- 125.

Cihan, N. (2014). Okullarda değerler eğitimi ve Türkiye'deki uygulamaya bir bakış. Turkish Studies International Periodical For the Languages, Literature and History of Turkish or Turkic. 9. (2), 429-436.

Dereli, i. E. (2014). Değerler eğitimi programının 5-6 yaş çocukların sosyal gelişimine etkisi: Sosyal beceri, psiko-sosyal gelişim ve sosyal problem çözme becerisi. Kuram ve Uygulamada Eğitim Bilimleri. 14. (1), 249-268.

Gürhan, E. (2017). Illkokullarda uygulanan değerler eğitimi uygulamalarının yönetici ve sınıf öğretmenlerinin görüşlerine göre değerlendirilmesi. Yayımlanmamış yüksek lisans tezi, Konya Necmettin Erbakan Üniversitesi EBE.

Hacıbektaşoğlu, E. S. (2014). Kültürel çalışmalar ve çizgi filmlerin çocuk izleyici üzerindeki etkileri araştırmaları. Yayımlanmamış yüksek lisans tezi, İstanbul: İstanbul Arel Üniversitesi.

Miles, M, B., \& Huberman, A. M. (1994). Qualitative data analysis: An expanded Source book. (2nd ed). Thousand Oaks, CA: Sage

Özdaş, F. (2013). Ortaokullarda değerler eğitimi ve istenmeyen öğrenci davranışlarına ilişkin öğretmen görüşlerinin değerlendirilmesi. Yayımlanmamış doktora tezi, Elâzığ: Fırat Üniversitesi EBE.

Sapsağlam, Ö. (2015). Anasınıfına devam eden çocuklara uygulanan sosyal değerler eğitimi programının sosyal beceri kazanımına etkisinin incelenmesi. Yayımlanmamış doktora tezi, Ankara: Gazi Üniversitesi.

Senek, S. (2018). Aytül Akal’ ın masallarının değerler eğitimi açısından değerlendirilmesi. Yayımlanmamış yüksek lisans tezi, Antalya: Akdeniz Üniversitesi EBE.

Silverman, D. (2001). Interpreting qualitative data: Methodsfor analysing talk. text and Interaction. London: SAGE Publication.

Talim ve Terbiye Kurulu Başkanlığı (2017). Müfredatta yenileme ve değişiklik çalışmalarımız üzerine basın açıklaması. Ankara. 
Tavşancıl, E. ve Aslan, E. (2001). İçerik analizi ve uygulama örnekleri. (1.Baskı). İstanbul: Epsilon Yayıncılık

Türkmen, N. (2012). Çizgi filmlerin kültür aktarımındaki rolü ve Pepee. Cumhuriyet Üniversitesi Sosyal Bilimler Dergisi. 36. (2), 139-158.

Topçuoğlu, N. (2003). Çocuklara yönelik televizyon reklamlarında atlatıcı ve yanıltııı unsurların analizi. Yayınlanmamış doktora tezi, Konya: Selçuk Üniversitesi Sosyal Bilimler Enstitüsü

Türk Dil Kurumu. (2011). Türkçe sözlük. (11. Baskı). Ankara: Türk Dil Kurumu Yayınları.

Ünlü, Ayşe S. (2017). Toplumsal cinsiyet rolleri bakımından TRT çocuk kanalında yayımlanan çizgi filmler. Yayımlanmamış yüksek lisans tezi, Erzincan: Erzincan Üniversitesi.

Yaşar, E. F. (2015). Çizgi filmlerin çocuklar üzerindeki etkilerine ilişkin çok boyutlu bir değerlendirme. Türk ve İslam Dünyası Sosyal Araştırmalar Dergisi. 2. (5), 70-84.

Yıldırım, A. ve Şimşek H. (2013). Sosyal bilimlerde nitel araştırma yöntemleri. Ankara: Seçkin Yayınclık.

Yorulmaz, B. (2013). Pepee çizgi filminin din ve değerler eğitimi açısından değerlendirilmesi. Uluslararası Sosyal Araştırmalar Dergisi, 6. (24), 438- 448.

MEB. (2013). Millî Eğitim Bakanlı̆̆ı, http://mebk12.meb.gov.tr/meb_iys_dosyalar /10/05/743046/ dosyalar/ 2013_ 02/24015229_ deerlereitimiynergesi.pdf, http://www.netco.com.tr/wp-content/uploads/2016/04/Sektor_Rapor.pdf Erişim: 03.08.2016. 